DOI https://doi.org/10.30525/978-9934-26-007-0-7

\title{
КРИМІНАЛЬНО-ПРАВОВА Й АДМІНІСТРАТИВНО-ПРАВОВА ВІДПОВІДАЛЬНІСТЬ НОТАРІУСА: ПОРІВНЯЛЬНО-ПРАВОВИЙ АНАЛІЗ
}

\author{
Вдовічен В. А., Вдовічена Л. І.
}

\section{ВСТУП}

Як незалежний і необхідний елемент регулювання відносин за участю нотаріусів юридична відповідальність характеризується трьома специфічними ознаками: вона виражається як вид державного примусу, що може бути застосований до нотаріуса; виключною підставою до ії застосування $є$ правопорушення, що вчиняється при здійсненні нотаріальної діяльності; вона функціонує шляхом застосування конкретних негативних заходів до осіб/нотаріусів, що скоїли правопорушення при виконанні своїх професійних обов'язків.

Застосування до нотаріуса/правопорушника юридичної відповідальності в демократичній, правовій державі обов'язково має відповідати провідним цілям і завданням, які встановлює держава щодо особи в суспільстві, стану законності та правопорядку тощо. Тому метою відповідальності нотаріуса/ правопорушника, iї керівною функцією не може бути просте покарання особи за тим принципом, як у давні часи - «око за око зуб за зуб». Варто відмітити, що якщо сутність відповідальності в усі часи залишалася такою ж - покарати винну особу, то цілі покарання, як і цілі юридичної відповідальності, ставали 3 часом більш багатофункціональними та динамічними, вони підпадали під значні зміни в ході історичного розвитку суспільства й держави. Проминув довгий і складний час від ігнорування людини, іiі гідності, прав i свобод i аж до визнання людини на конституційному рівні найвищою соціальною цінністю, захист якої $\epsilon$ обов'язком посадових осіб, які здійснюють свої професійні функції. I саме в такому ракурсі ми будемо вести мову про юридичну відповідальність нотаріуса як суб'єкта виконання покладених на нього професійних обов'язків ${ }^{1}$.

Юридичну відповідальність нотаріуса/правопорушника можна класифікувати за різними ознаками. Найдоцільнішою в практичному значенні можна вважати класифікацію за характером санкцій і за галузевою ознакою. Згідно з галузевою ознакою, виділяють такі види юридичної відповідальності нотаріуса, як кримінальна, адміністративна, дисциплінарна, цивільноправова. Метою дослідження є проведення порівняльно-правового аналізу кримінально-правової та адміністративно-правової відповідальності.

\footnotetext{
${ }^{1}$ Vdovichen V., Vdovichena, L. Professional Responsibility of Notaries: Ontological Aspect. Eur. JL \& Pub. Admin. 2019. № 6. P. 148.
} 


\section{1. Юридична конструкція та особливості}

\section{кримінально-правової відповідальність нотаріуса}

Найбільш суворим видом галузевої юридичної відповідальності $\epsilon$ кримінальна відповідальність. Вона настає лише внаслідок скоєння злочину - суспільно небезпечного діяння, склад якого встановлений i передбачений у кримінальному законі. Поняття злочину та покарання, а також чіткий перелік злочинних діянь, заборонених кримінальним законом, і відповідних їм кримінальних покарань закріплено в Кримінальному кодексі (далі - КК) України. Порядок застосування кримінальної відповідальності чітко регламентований і встановлений виключно Кримінальним процесуальним кодексом України. До кримінальної відповідальності особа (у тому числі й нотаріус), винна в скоєнні злочину, може бути притягнена виключно судом. Ніхто не може бути визнаний винним у скоєнні злочину, а також покараний інакше, ніж за вироком суду та відповідно до закону. Кримінальні покарання серед усіх інших заходів примусу $є$ найбільш суворими та жорсткими формами державного примусу, що впливають переважно на особу злочинця: їх мета $\epsilon$ його перевиховання та запобігання скоєнню злочинів у майбутньому, однак істотно обмежуючи його правовий статус. Серед найпоширеніших покарань можна назвати такі з них, як позбавлення волі, виправні роботи, заборона обіймати певну посаду або займатися певною діяльністю, конфіскація майна тощо. Відбуття кримінального покарання тягне також для злочинця настання відповідних юридичних наслідків, а саме протягом певного часу за ним зберігається судимість.

Кримінальне законодавство України «не знає» та «ніколи не знало» такого окремого поняття чи категорії, як «злочини у сфері нотаріальної діяльності». За радянських часів злочинні дії, що здійснювалися у сфері нотаріату, чітко вписувалися в групу посадових злочинів, а все тому, що статус нотаріуса розглядався як статус посадової особи органів юстиції. Ранне кримінальне законодавство України перейняло цю традицію, саме тому до прийняття чинного КК України навіть саме слово «нотаріус» ні один раз не вживалося, виходило, що нотаріуси не могли бути учасниками кримінально-правових відносин. Ситуація змінилася 3 прийняттям Кримінального кодексу України 2001 року, у якому вже відчутне розуміння специфічного особливого правового статусу нотаріуса. Він визначався як особа, до якої не може бути застосоване покарання у вигляді виправних робіт (стаття 57 КК України), а приватний нотаріус - як особа, що видає або посвідчує документи, що є предметом злочину, передбаченого статтею 358 КК України «Підроблення документів, печаток, штампів та бланків, їх збут, 
використання підроблених документів» ${ }^{2}$. Однак водночас до безпосереднього визнання нотаріуса спеціальним суб'єктом злочину саме як нотаріуса, а не як посадової (службової) особи було ще досить далеко.

Значимість проблеми кримінальної відповідальності нотаріуса підтверджується інтенсивним реформуванням законодавства у важливих суспільних правовідносинах, яке відбувається протягом останнього часу. Актуальною темою в нотаріальній спільноті й у суспільстві зокрема стала реформа у сфері реєстрації речових прав на нерухоме майно і бізнесу та делегування державою спеціальних повноважень нотаріусу. Так, 6 жовтня 2016 року Верховною Радою України прийнято Закон України «Про внесення змін до деяких законодавчих актів України щодо вдосконалення державної реєстрації прав на нерухоме майно та захисту прав власності» № 1666-VIII ${ }^{3}$, який отримав серед правознавців назву «антирейдерський». 3 метою захисту прав власності під час реєстраційних дій, посилення адміністративної та кримінальної відповідальності суб'єктів реєстраційних дій, учасників незаконної змови, зазначеним Законом передбачено певні нововведення, у тому числі й у діяльність нотаріусів як державних реєстраторів. Як відмічає А.С. Гончарова, оцінюючи ефективність кримінально-правової протидії зловживанням нотаріусів, доводиться визнати, що вона дуже далека від оптимальної, про що, зокрема, свідчать відсутність необхідної однаковості в практиці застосування кримінальноправових норм про відповідальність нотаріусів за зловживання своїми повноваженнями, наявність прогалин у кримінальному законодавстві, яке не передбачає відповідальності за низку суспільно небезпечних діянь, що вчиняються нотаріусами, і високий рівень латентності відповідних діянь ${ }^{4}$.

Відповідно до статті 38 Закону України «Про внесення змін до деяких законодавчих актів України щодо вдосконалення державної реєстрації прав на нерухоме майно та захисту прав власності», нотаріус як державний реєстратор за порушення законодавства у сфері державної реєстрації прав несе кримінальну відповідальність у порядку, установленому законом .

\footnotetext{
${ }^{2}$ Кримінальний кодекс України від 05.04.2001 № 2341-III (у редакції від 27.06.2019) / Верховна Рада України. URL: https://zakon.rada.gov.ua/laws/show/2341-14\#Text (дата звернення: 02.11.2020).

${ }^{3}$ Про внесення змін до деяких законодавчих актів України щодо вдосконалення державної реєстрації прав на нерухоме майно та захисту прав власності : Закон України від 6 жовтня 2016 р. № 1666-VIII / Верховна Рада України. URL: http://zakon5.rada.gov.ua/laws/show/1666-19 (дата звернення: 02.11.2020).

${ }^{4}$ Гончарова А.С. До питання кримінальної відповідальності нотаріуса. Молодий вчений. 2018. № 10 (62). C. 227-231.

${ }^{5}$ Про державну реєстрацію речових прав на нерухоме майно та їх обтяжень : Закон України від 1 липня 2004 p. № 1952-IV / Верховна Рада України. URL: http://zakon0.rada.gov.ua/laws/show/1952-15 (дата звернення: 06.11.2020).

Про державну реєстрацію юридичних осіб, фізичних осіб-підприємців та громадських формувань : Закон України від 15 травня 2003 р. № 755-IV / Верховна Рада України. URL: http://zakon3.rada.gov.ua/laws/ show/755-15 (дата звернення: 06.11.2020).
} 
Шкода, завдана державним реєстратором фізичній чи юридичній особі під час виконання своїх обов'язків, підлягає відшкодуванню на підставі рішення суду, що набрало законної сили, у порядку, установленому законом. При цьому КК України не встановлено окремого складу злочину у сфері державної реєстрації речових прав на нерухоме майно та державної реєстрації бізнесу. Отже, нотаріуси як державні реєстратори можуть бути притягнуті до кримінальної відповідальності лише за наявності в їхніх діях або бездіяльності фактичного складу злочину, передбаченого КК України. Так, для порівняння варто зазначити, що статтею 170 Кримінального кодексу Російської Федерації передбачено такий склад злочину - «Регистрация заведомо незаконных сделок с землей, искажение сведений государственного кадастра недвижимости, а равно умышленное занижение размеров платежей за землю, если эти деяния совершены из корыстной или иной личной заинтересованности должностным лицом с использованием служебного положения, - наказываются...» ${ }^{6}$. Отже, у КК Російської Федерації встановлено кримінальну відповідальність за злочин у сфері державної реєстрації прав, зокрема за реєстрацію незаконних договорів із землею.

Наступним (але, як видається, не останнім) кроком законодавця в розширенні кримінально-правового статусу нотаріуса стало реформування чинного законодавства України щодо запобігання корупції та боротьби 3 нею загалом i зокрема його кримінально-правової частини. Варто відзначити, що у зв'язку 3 прийняттям Закону України «Про засади запобігання і боротьби з корупцією» ${ }^{7}$, який утратив чинність 1 вересня 2016 року, коло суб'єктів корупційних правопорушень було значно розширене, а КК України був доповнений цілою низкою статей про нові злочини у сфері службової діяльності. Серед них виняткової уваги в межах дослідження варта стаття 365-2 «Зловживання повноваженнями особами, які надають публічні послуги» і стаття 368-4 «Підкуп особи, яка надає публічні послуги», адже саме тут нотаріус визначається як спеціальний суб'єкт злочину безпосередньо в диспозиціях кримінально-правових норм, передбачених указаними статтями. Необхідність такої криміналізації цього роду діянь назрівала досить давно, оскільки саме нотаріуси не є представниками влади або місцевого самоврядування, а тому вони не були суб'єктами злочинів, передбачених статтями 364, 365, 368 КК України, і така ситуація на практиці давала можливість часто уникати відповідальності нотаріусами. Наприклад, російський законодавець уже досить давно

\footnotetext{
6 Уголовный кодекс Российской Федерации от 13 июня 1996 г. № 63-Ф3 (ред. от 3 июля 2018 г.). URL: http://ppt.ru/kodeks.phtml?kodeks=20 (дата звернення: 06.11.2020).

${ }^{7}$ Про засади запобігання і боротьби з корупцією : Закон України. Відомості Верховної Ради Украӥни (ВВР). 2011. № 40. Ст. 404 (утратив чинність 01.09.2016).
} 
усвідомив таку проблему, результатом чого було включення до нового КК Російської Федерації статті 202 «Зловживання повноваженнями приватними нотаріусами та аудиторами».

Як результат законотворчої діяльності коло злочинів, спеціальними суб'єктами яких можуть бути як державні, так і приватні нотаріуси як особи, на яких покладено виконання функцій держави, обмежується статтями 232-1, 365-2, 368-4 КК України: стаття 232-1 «Незаконне використання інсайдерської інформації» - умисне незаконне розголошення, передача або надання доступу до інсайдерської інформації, а так само надання 3 використанням такої інформації рекомендацій стосовно придбання або відчуження цінних паперів чи похідних (деривативів), якщо це призвело до отримання особою, яка вчинила зазначені дії, чи третіми особами необгрунтованого прибутку в значному розмірі, або уникнення учасником фондового ринку чи третіми особами значних збитків, або якщо це заподіяло значну шкоду охоронюваним законом правам, свободам та інтересам окремих громадян або державним чи громадським інтересам, або інтересам юридичних осіб, - караються штрафом від семисот п'ятдесяти до двох тисяч неоподатковуваних мінімумів доходів громадян, 3 позбавленням права обіймати певні посади або займатися певною діяльністю на строк до трьох років або без такого. Згідно із цією ж статтею, дається пояснення, хто саме належить до таких осіб - «під особами, які вчинили дії, передбачені цією статтею, розуміються: посадові особи емітента, у тому числі ті, які були посадовими особами емітента на момент ознайомлення з інсайдерською інформацією; особи, які мають доступ до інсайдерської інформації у зв'язку 3 виконанням ними трудових (службових) обов'язків або договірних зобов'язань незалежно від відносин 3 емітентом, у тому числі співробітники професійних учасників фондового ринку; державні службовці, яким відома інсайдерська інформація внаслідок виконання ними посадових (службових) обов'язків; особи, які ознайомилися 3 інсайдерською інформацією неправомірним шляхом; аудитори, нотаріуси, експерти, оцінювачі, арбітражні керуючі або інші особи, які виконують надані законом публічні повноваження» ${ }^{8}$.

Стаття 365-2 «Зловживання повноваженнями особами, які надають публічні послуги» - зловживання своїми повноваженнями аудитором, нотаріусом, оцінювачем, уповноваженою особою або службовою особою Фонду гарантування вкладів фізичних осіб, іншою особою, яка не $\epsilon$ державним службовцем, посадовою особою місцевого самоврядування, але здійснює професійну діяльність, пов'язану з наданням публічних послуг,

\footnotetext{
${ }^{8}$ Кримінальний кодекс України від 05.04.2001 № 2341-III (у редакції від 27.06.2019) / Верховна Рада України. URL: https://zakon.rada.gov.ua/laws/show/2341-14\#Text (дата звернення: 02.11.2020).
} 
у тому числі послуг експерта, арбітражного керуючого, приватного виконавця, незалежного посередника, члена трудового арбітражу, третейського судді (під час виконання цих функцій), або державним реєстратором, суб'єктом державної реєстрації прав, державним виконавцем, приватним виконавцем з метою отримання неправомірної вигоди, якщо це завдало істотної шкоди охоронюваним законом правам або інтересам окремих громадян, державним чи громадським інтересам або інтересам юридичних осіб, - карається обмеженням волі на строк до трьох років 3 позбавленням права обіймати певні посади чи займатися певною діяльністю на строк до десяти років ${ }^{9}$.

Злочин, котрий передбачений статтею 365-2 КК України, має безпосередньо матеріальний склад, оскільки його об'єктивна сторона чітко охоплює суспільно небезпечні наслідки діяння, які можуть мати вираження або у вигляді істотної шкоди (ч. 1, ч. 2 ст. 365-2), або у вигляді тяжких наслідків (ч. 3 ст. 365-2). Також згідно $з$ пунктом 3 примітки до статті 364 КК України, якщо такі наслідки полягають у завданні матеріальних збитків, вони мають бути не меншими за 100 або 250 неоподатковуваних мінімумів доходів громадян відповідно.

Також досить схожою є ситуація в статті 364 КК України, яка є загальною нормою щодо інших кримінально-правових норм, які передбачають відповідальність за злочини у сфері службової діяльності, стаття 365-2 КК України $є$ загальною щодо всіх решти норм, якими встановлена відповідальність нотаріусів за злочинні діяння, пов'язані зі здійсненням ними незалежної професійної діяльності. Наприклад, спеціальним видом зловживання нотаріусом своїми повноваженнями (обов'язками) варто вважати діяння, передбачене статтею 232-1 КК України, оскільки інсайдерська інформація стає відомою нотаріусу безпосередньо у зв'язку з виконанням ним своїх професійних обов'язків, на нотаріуса покладається обов'язок не використовувати цю інформацію в цілях, які не передбачені законодавством.

Стаття 368-4 «Підкуп особи, яка надає публічні послуги» - пропозиція чи обіцянка аудитору, нотаріусу, оцінювачу, іншій особі, яка не є державним службовцем, посадовою особою місцевого самоврядування, але провадить професійну діяльність, пов'язану 3 наданням публічних послуг, у тому числі послуг експерта, арбітражного керуючого, приватного виконавця, незалежного посередника, члена трудового арбітражу, третейського судді (під час виконання цих функцій), надати йому/їй або третій особі неправомірну вигоду, а так само надання такої вигоди або прохання іiі надати за вчинення особою, яка надає публічні послуги, дій або іiі бездіяльність

\footnotetext{
${ }^{9}$ Кримінальний кодекс України від 05.04.2001 № 2341-III (у редакції від 27.06.2019) / Верховна Рада України. URL: https://zakon.rada.gov.ua/laws/show/2341-14\#Text (дата звернення: 02.11.2020).
} 
з використанням наданих їй повноважень в інтересах того, хто пропонує, обіцяє чи надає таку вигоду, або в інтересах третьої особи, - караються штрафом від ста п'ятдесяти до чотирьохсот неоподатковуваних мінімумів доходів громадян або громадськими роботами на строк від ста до двохсот годин, або обмеженням волі на строк до двох років, або позбавленням волі на той самий строк ${ }^{10}$.

Варто також відзначити й такий злочин, спеціальним суб'єктом якого можуть бути нотаріуси, як діяння, передбачене статтею 209-1 КК України, умисне порушення вимог законодавства про запобігання та протидію легалізації (відмиванню) доходів, одержаних злочинним шляхом, або фінансування тероризму. Водночас, відповідно до пунктів «г» п. 8 ч. 2 статті 5 Закону України «Про запобігання та протидію легалізації (відмиванню) доходів, одержаних злочинним шляхом, або фінансуванню тероризму», нотаріуси разом 3 іншими суб'єктами незалежної професійної діяльності зараховані саме до спеціально визначених суб'єктів фінансового моніторингу.

Разом із тим злочини, які вчиняються у сфері нотаріальної діяльності, не обмежуються лише наведеним вище переліком діянь. Ураховуючи коло суб'єктів, які уповноважені законом на вчинення нотаріальних дій, до злочинів у сфері нотаріальної діяльності можна зарахувати й суспільно небезпечні діяння, що вчиняються службовими особами органів державної влади та місцевого самоврядування під час реалізації ними делегованих (що стосується нотаріусів) повноважень.

\section{2. Юридична конструкція та особливості адміністративно-правової відповідальність нотаріуса}

Адміністративна відповідальність уважається менш суворою (порівняно 3 кримінальною відповідальністю) і настає в разі вчинення адміністративних проступків, передбачених законодавством про адміністративні правопорушення, і може виражатися у винесенні попередження, накладенні штрафу, позбавленні спеціальних прав, адміністративному затриманні або арешті, огляді речей, а також у вилученні речей і документів.

На додаткову особливу увагу сьогодні заслуговує так звана адміністративна відповідальність державного нотаріуса. Але в цьому випадку передусім доцільно визначитися 3 дефініцією й ознаками адміністративної відповідальності, 3 огляду на те що на законодавчому рівні категорія адміністративної відповідальності не визначена. Аналіз наукових доробків із цього питання Ю.С. Шемшученка, А.Б. Турчина, В.В. Копейчикова та Р.С. Павловського, Ю.П. Битяка та В.В. Зуя, В.К. Колпакова,

\footnotetext{
${ }^{10}$ Кримінальний кодекс України від 05.04.2001 № 2341-III (у редакції від 27.06.2019) / Верховна Рада України. URL: https://zakon.rada.gov.ua/laws/show/2341-14\#Text (дата звернення: 02.11.2020).
} 
I.В. Гаврущенко, Л. Коваля, Є. Додіна й інших дає можливість стверджувати, що адміністративна відповідальність - це застосування засобів та інструментів примусового впливу, які виражаються в установленні обмежень особистого, майнового (матеріального), морального або іншого (визначеного законодавством) характеру уповноваженими органами (посадовими особами) до фізичних осіб, юридичних осіб за вчинення адміністративного проступку в порядку, передбаченому адміністративним законодавством ${ }^{11}$.

Науковці-теоретики відзначають, що адміністративній відповідальності характерні певні ознаки. А.Б. Агапон, наприклад, визначає такі особливості адміністративної відповідальності: 1) застосовується за правопорушення, що не мають високого ступеня суспільної небезпеки й мають назву «адміністративні проступки (правопорушення)»; 2) є наслідком протиправної дії чи бездіяльності юридичної особи або фізичної особи. У вказаних правовідносинах завжди бере участь суб'єкт публічно-правової сфери; 3) є результатом правопорушення у сфері виключно загальнодержавних інтересів $^{12}$. У такому ракурсі можна говорити, що однією з провідних ознак адміністративної відповідальності $\epsilon$ те, що вона $\epsilon$ наслідком правопорушення у сфері загальнодержавних інтересів. Однак сьогодні в Україні нотаріус не володіє статусом державного службовця, представника влади, але він виконує покладені на нього державою чіткі спеціальні повноваження, що є частиною державної системи чи органу, наділеного публічною владою ${ }^{13}$. Ми не заперечуємо, що між адміністративною та нотаріальною діяльністю «існує суттєва відмінність за юридичним характером, а також колом суб'єктів і структурою їх правовідносин, метою, результатами та методами регулювання» ${ }^{14}$, та й законодавством про нотаріат не передбачено притягнення нотаріуса до адміністративної відповідальності. Однак водночас Кодексом України про адміністративні правопорушення передбачені та встановлені склади правопорушень, суб'єктами яких $\epsilon$ нотаріуси. Згідно зі статтею 163-9 Кодексу України про адміністративні правопорушення (далі - КУпАП), установлено відповідальність за незаконне використання інсайдерської інформації та чітко встановлено перелік осіб, які можуть бути притягнути до адміністративної відповідальності відповідно до цієї статті, до якого включено також і нотаріуса. Крім того, главою 13-А «Адміністративні правопорушення,

\footnotetext{
${ }^{11}$ Висєканцев О.О. Адміністративна відповідальність державного нотаріусу. Актуальні проблеми права: теорія і практика. 2012. № 25. C. 190-197. URL: http://nbuv.gov.ua/UJRN/app_2012_25_23 (дата звернення: 02.11.2020).

${ }_{12}$ Агапов А.Б. Административная ответственность : учебник. Москва : Статут, 2000. С. 10.

${ }_{13}^{13}$ Москаленко И.В. Сущность и значение нотариата. Нотариус. 2002. № 5. С. 6.

${ }^{14}$ Комаров В. Проблеми латинського нотаріату: український досвід нормоутворення. Вісник Академї правових наук Украӥни : збірник наукових праць. 2007. № 1 (48). С. 137.
} 
пов'язані 3 корупцією» вищезазначеного Кодексу встановлено правопорушення, які пов'язані з проявами корупційних діянь, суб'єктами яких також визначені нотаріуси ${ }^{15}$. Отже, складаються обставини, коли законодавством про нотаріат України сьогодні не передбачено притягнення нотаріуса до адміністративної відповідальності, а галузевим адміністративним законодавством установлено конкретні правопорушення, суб' єктами яких визначено нотаріусів. А.Н. Міронов стверджує, з чим ми погоджуємося, що «бажано було б закріпити самостійні склади адміністративних правопорушень, суб'єктами яких виступав би нотаріус, причому як такий, що працює в державній нотаріальній конторі, так і такий, що займається приватною практикою» ${ }^{16}$. Крім того, ми вважаємо, що не доречно однозначно заявляти, що нотаріус не є представником влади, а також не виконує делеговані державою функції та дії його неможливо розглядати в порядку адміністративного судочинства. Оскільки державою безпосередньо встановлено порядок доступу до професії нотаріуса (конкретний обсяг правосуб'єктності, обов'язкове проходження стажування, а також складання кваліфікаційного іспиту), через Міністерство юстиції держава наділяє таку особу, яка претендує на посаду, статусом нотаріуса, що підтверджується відповідним виданим свідоцтвом про право на зайняття нотаріальною діяльністю встановленого спеціального зразка та наділяє його спеціальними повноваженнями, установивши в конкретних випадках вимогу обов'язкового вчинення нотаріальних дій. Юристами-науковцями та практиками відмічається, що «нотаріат володіє дуалістичною природою, у силу якої, з одної сторони, нотаріус виступає в якості уповноваженого представника держави, а з іншого - як незалежний юридичний консультант сторін, і як представник вільної професії» ${ }^{17}$. Однак отримати консультацію фізичні та юридичні особи можуть і в представників інших професій, а вчиняти нотаріальні дії уповноважений лише конкретно визначене коло посадових осіб. Підсумовуючи, варто піддати сумніву загальноприйняту позицію, що нотаріус не може бути притягнутий до адміністративної відповідальності, тому що він не $\epsilon$ державним службовцем, представником влади. Установлено, що КУпАП закріплено види правопорушень, суб'єктами яких визнані нотаріуси. 3 огляду на це, пропонуємо зазначити, що нотаріус може бути притягнутий до адміністративної відповідальності. Разом із тим постає

\footnotetext{
${ }^{15}$ Кодекс України про адміністративні правопорушення від 07.12.1984 № 8073-Х (редакція від 03.07.2019) / Верховна Рада України. URL: https://zakon.rada.gov.ua/laws/show/80731-10\#Tеxt (дата звернення: 10.11.2020).

${ }_{16}^{16}$ Миронов А.Н. Нотариат : учебное пособие. Москва : Форум ; Инфра-М, 2005. С. 75-76.

17 Зілковська К.Л. Судова юрисдикція справ щодо оскарження нотаріальних дій та відмови у їх вчиненні. C. 44. Веб-сайт Національної бібліотеки Украӥни імені B.I. Вернадського. URL: http://www.nbuv.gov.ua/ portal/Soc_Gum/Vonu_prav/2010_22/06.pdf (дата звернення: 10.11.2020).
} 
питання щодо порядку оскарження дій (бездіяльності) або відмови в учинення нотаріальних дій. Законодавства Російської Федерації, Республік Молдови, Білорусь, Казахстан установлюють, що оскарження дій або відмова в учиненні нотаріальних дій у цих країнах здійснюється в судах загальної юрисдикції в порядку цивільного судочинства. Однак в Україні сьогодні цивільним процесуальним законодавством не передбачено порядку оскарження дій або відмови в учиненні нотаріальних дій ${ }^{18}$. Також, звертаючи увагу на те, що нотаріус при вчиненні нотаріальних дій виконує функції, якими його наділяє держава, від імені держави, варто порушити питання щодо реальної можливості оскарження дій (бездіяльності) нотаріуса або ж відмови в учиненні нотаріальних дій у порядку спеціального адміністративного судочинства.

Крім того, на противагу кримінально-правовим заходам, в основу яких передусім покладено ознаку караності (тобто певної своєрідної відплати винному за вчинений ним злочин) i спеціальну мету запобігання злочинам - створення умов, що унеможливлюють або ж ускладнюють можливість учинення нових подібних злочинів ${ }^{19}$, адміністративно-правові заходи безпосередньо поєднують державний примус і моральний вплив. Специфічна соціальна роль адміністративної відповідальності стає надзвичайно цінною насамперед тому, що вона виражається як правовий наслідок неналежної реалізації нотаріусами своїх прав та обов'язків при здійсненні нотаріальної діяльності. Вона включає не лише ретроспективну відповідальність як результат правопорушення, а й позитивний момент, тобто специфічний внутрішній стан особи, іiі ставлення до справи, суспільства, своєї поведінки ${ }^{20}$. Якщо ж все-таки порівнювати адміністративну та цивільно-правову відповідальність, варто врахувати, що остання настає за порушення обов'язків, які випливають із цивільно-правових договорів, тобто угод, які виникають між рівноправними сторонамисуб'єктами, а адміністративна відповідальність, навпаки, передбачає нерівність сторін відносин ${ }^{21}$. Специфіка адміністративної відповідальності нотаріуса ще й у тому, що вона не ставить завданням поновлення порушених прав нотаріусом, компенсації завданих ним матеріальних збитків, а лише виконує переважно охоронну та превентивну функції. Але спрямованість захисної функції адміністративної відповідальності

\footnotetext{
${ }^{18}$ Висєканцев О.О. Адміністративна відповідальність державного нотаріусу. Актуальні проблеми права: теорія і практика. 2012. № 25. С. 190-197.

${ }^{19}$ Кримінальне право України. Загальна частина : підручник / за ред. М.І. Мельника, В.А. Клименка. 5 вид., переробл. та допов. Київ : Атіка, 2009. С. 227-228.

${ }^{20}$ Адміністративне право. Загальна частина : навчальний посібник / С.М. Алфьоров, С.В. Ващенко, М.М. Долгополова, А.П. Купін. Київ : Центр учбов. літ., 2011. С. 82.

21 Адміністративне право України : підручник / за ред. Ю. П. Битяка. Київ : Юрінком Інтер, 2007. C. $172-174$.
} 
нотаріусів часто виходить за межі суто адміністративно-правових відносин і в установлених законом випадках часто здійснює охорону відносин, урегульованих нормами деяких інших галузей права. Крім того, реалізація адміністративної відповідальності (застосування та виконання санкції) має на меті виховання особи-нотаріуса, яка вчинила адміністративне правопорушення, у напрямі додержання законів України, поваги до правил співжиття, а також запобігання вчиненню нових правопорушень як самим правопорушником (нотаріусом), так й іншими особами (стаття 23 КУПАП).

Специфічною особливістю адміністративної відповідальності нотаріусів $€$ також спрощена процедура та підвищена економічність іiі можливого застосування. Адміністративна відповідальність нотаріусів у сфері фінансивого моніторингу встановлюється на рівні КУПАП і Закону України «Про запобігання та протидію легалізації (відмиванню) доходів, одержаних злочинним шляхом, фінансуванню тероризму та фінансуванню розповсюдження зброї масового знищення» ${ }^{22}$. КУПАП містить дві статті, пов'язанні 3 питанням фінансового моніторингу: статтю 166-9 - порушення законодавства щодо запобігання та протидії легалізації (відмиванню) доходів, одержаних злочинним шляхом, фінансуванню тероризму та фінансуванню розповсюдження зброї масового знищення; статтю 188-34 - невиконання законних вимог посадових осіб суб'єктів державного фінансового моніторингу. Адміністративна відповідальність у порядку КУпАП накладається судами за наслідками розгляду протоколів про адміністративні правопорушення, що складається уповноваженими на те посадовими особами суб'єктів державного фінансового моніторингу. Статтею 24 Закону передбачено застосування санкцій у вигляді штрафу за невиконання вимог Закону та/або нормативно-правових актів, що регулюють діяльність у сфері запобігання та протидії легалізації (відмиванню) доходів, одержаних злочинним шляхом, а саме за порушення вимог щодо ідентифікації, верифікації, вивчення клієнтів (осіб) у випадках, передбачених законодавством; невиявлення, несвоєчасне виявлення та порушення порядку реєстрації фінансових операцій, що, відповідно до законодавства, підлягають фінансовому моніторингу; неподання, несвоєчасне подання, порушення порядку подання або подання спеціально уповноваженому органу недостовірної інформації у випадках, передбачених законодавством; порушення порядку зупинення фінансової (фінансових) операції (операцій); неподання, подання не в повному обсязі, подання недостовірної інформації/документів, подання копій документів, у яких неможливо

\footnotetext{
${ }^{22}$ Про запобігання та протидію легалізації (відмиванню) доходів, одержаних злочинним шляхом, фінансуванню тероризму та фінансуванню розповсюдження зброї масового знищення : Закон України від 14.10.2014 № 1702-VII (у редакції від 24.11.2018). Відомості Верховної Ради України (ВВР). 2014. № 50-51. Ст. 2057.
} 
прочитати всі написані в них відомості, на запит суб'єкта державного фінансового моніторингу, необхідних для виконання ним функцій 3 державного регулювання й нагляду відповідно до цього Закону, або втрату документів (у тому числі інформації про рахунки або активи); порушення обов'язків, визначених цим Законом i/або нормативно-правовими актами у сфері запобігання і протидії легалізації (відмиванню) доходів, одержаних злочинним шляхом, фінансуванню тероризму та фінансуванню розповсюдження зброї масового знищення.

Органом, уповноваженим на застосування санкцій щодо нотаріусів, за цією нормою Закону, є Міністерство юстиції України, в також головні територіальні управління юстиції областей. Факти порушень вимог законодавства у сфері фінансового моніторингу виявляються посадовими особами органів юстиції під час здійснення нагляду за діяльністю нотаріусів, зокрема шляхом проведення планових і позапланових перевірок. Справа про порушення вимог законодавства у сфері фінансового моніторингу розглядається за участю нотаріуса, стосовно якого розглядається справа. Орган юстиції повідомляє нотаріуса про дату й час розгляду справи про порушення вимог законодавства у сфері фінансового моніторингу не пізніше ніж за 15 календарних днів до дати її розгляду.

Санкції до нотаріусів застосовуються органами юстиції протягом шести місяців $з$ дня виявлення порушення, але не пізніше ніж через три роки 3 дня його вчинення. Рішення про застосування санкцій за вчинене правопорушення приймається Комісією органів юстиції. За результатами розгляду матеріалів справи про порушення вимог законодавства, що регулює діяльність у сфері фінансового моніторингу, Комісія приймає рішення про застосування санкцій до нотаріуса або про закриття провадження у справі, яке оформлюється відповідною постановою. Постанова про застосування штрафних санкцій підлягає виконанню нотаріусом протягом п'ятнадцяти робочих днів 3 дня ії отримання. Після перерахування суми штрафу нотаріус надсилає, відповідно, органу юстиції копію квитанції або іншого платіжного документа про сплату штрафу.

У разі невиконання нотаріусом постанови про застосування штрафних санкцій у встановлений строк постанова передається до органів державної виконавчої служби для примусового виконання. Оскарження постанови здійснюється в судовому порядку виключно 3 метою встановлення законності прийняття зазначеної постанови та не зупиняє виконання нотаріусом застосованої санкції. 


\section{ВИСНОВКИ}

Кримінальна відповідальність нотаріуса свою значимість набуває у зв'язку 3 інтенсивним реформуванням законодавства, яке відбувається протягом останнього часу, - реформою у сфері реєстрації речових прав на нерухоме майно і бізнес, а також делегування державою спеціальних повноважень нотаріусу. Коло злочинів, спеціальними суб'єктами яких можуть бути як державні, так і приватні нотаріуси як особи, на яких покладено виконання функцій держави, визначається статтями: незаконне використання інсайдерської інформації; зловживання повноваженнями особами, які надають публічні послуги; підкуп особи, яка надає публічні послуги. Крім того, злочини у сфері нотаріальної діяльності не обмежуються наведеним вище переліком діянь. 3 огляду на коло суб'єктів, уповноважених законом на вчинення нотаріальних дій, до злочинів у сфері нотаріальної діяльності доводиться зарахувати й суспільно небезпечні діяння, що вчиняються службовими особами органів державної влади та місцевого самоврядування під час реалізації цих повноважень. Однак кваліфікація цих діянь грунтується на їхньому статусі службових осіб.

Тому причина наявних відмінностей у межах криміналізації суспільно небезпечних діянь, скоєних суб'єктами нотаріальної діяльності, полягає в наділенні останніх різним кримінально-правовим статусом: державні нотаріуси та інші суб'єкти нотаріальної діяльності є посадовими особами, тоді як приватні нотаріуси не визнаються такими.

Адміністративна відповідальність нотаріуса - це один із видів юридичної відповідальності, який утілює негативну реакцію з боку уповноважених суб'єктів на окреслені в законі правопорушення (проступки) у сфері професійної діяльності нотаріуса, а також на корупційні адміністративні правопорушення, які пов'язані 3 такою діяльністю. Адміністративноправова відповідальність нотаріуса полягає в застосуванні (з дотриманням установленої процедури) до нотаріусів як винних осіб передбачених законом санкцій - адміністративних стягнень. Отже, адміністративну відповідальність нотаріуса можна визнати як гарантію і засіб забезпечення прав і законних інтересів громадян і юридичних осіб під час учинення нотаріальних, реєстраційних дій, а також суспільних (державних) інтересів під час здійснення первинного фінансового моніторингу.

\section{АНОТАЦІЯ}

У розділі монографії проведено порівняльно-правовий аналіз кримінальноправової та адміністративно-правової відповідальності нотаріуса. Установлено, що комплексний характер юридичної відповідальність нотаріуса пояснюється тим, що, будучи уповноваженим державою на реалізацію 
публічно-правової функції, нотаріус відповідає за правомірність своєї діяльності як перед заявниками, так і перед суспільством в цілому. Аналіз кримінального законодавства України показує, що воно не знає такого окремого поняття, як «злочини у сфері нотаріальної діяльності». Кримінальноправова відповідальність нотаріуса свою значимість набуває узв'язку з інтенсивним реформуванням законодавства, яке відбувається протягом останнього часу, - реформою у сфері реєстрації речових прав на нерухоме майно і бізнесу, а також делегування державою спеціальних повноважень нотаріусу. Це спонукає до значного розширення кола злочинів, спеціальними суб'єктами яких можуть бути як державні, так і приватні нотаріуси як особи, на яких покладено виконання функцій держави. Основна причина наявних відмінностей у межах криміналізації суспільно небезпечних діянь, скоєних суб'єктами нотаріальної діяльності, полягає в наділенні останніх різним кримінально-правовим статусом: державні нотаріуси та інші суб'єкти нотаріальної діяльності є посадовими особами, тоді як приватні нотаріуси не визнаються такими. Адміністративно-правова відповідальність нотаріуса втілює негативну реакцію з боку уповноважених суб'єктів на окреслені в законі правопорушення (проступки) у сфері професійної діяльності нотаріуса, а також на корупційні адміністративні правопорушення, які пов'язані з такою діяльністю. Адміністративно-правова відповідальність нотаріуса полягає в застосуванні (з дотриманням установленої процедури) до нотаріусів як винних осіб передбачених законом санкцій - адміністративних стягнень. Отже, адміністративну відповідальність нотаріуса можна визнати як гарантію і засіб забезпечення прав і законних інтересів громадян і юридичних осіб під час учинення нотаріальних, реєстраційних дій, а також суспільних (державних) інтересів - під час здійснення первинного фінансового моніторингу.

\section{ЛITЕРАТУРА}

1. Кодекс України про адміністративні правопорушення від 07.12.1984 № 8073-X (редакція від 03.07.2019) / Верховна Рада України. URL: https://zakon.rada.gov.ua/laws/show/80731-10\#Техt (дата звернення: 10.11.2020).

2. Кримінальний кодекс України від 05.04.2001 № 2341-III (у редакції від 27.06.2019) / Верховна Рада України. URL: https://zakon.rada.gov.ua/laws/ show/2341-14\#Text (дата звернення: 02.11.2020).

3. Про внесення змін до деяких законодавчих актів України щодо вдосконалення державної реєстрації прав на нерухоме майно та захисту прав власності : Закон України від 6 жовтня 2016 р. № 1666-VIII / Верховна Рада України. URL:http://zakon5.rada.gov.ua/laws/show/1666-19 (дата звернення: 02.11.2020). 
4. Про державну реєстрацію речових прав на нерухоме майно та їх обтяжень : Закон України від 1 липня 2004 р. № 1952-IV / Верховна Рада України. URL: http://zakon0.rada.gov.ua/laws/show/1952-15 (дата звернення: 06.11.2020).

5. Про державну реєстрацію юридичних осіб, фізичних осіб-підприємців та громадських формувань : Закон України від 15 травня 2003 р. № 755-IV / Верховна Рада України. URL: http://zakon3.rada.gov.ua/laws/show/755-15 (дата звернення: 06.11.2020).

6. Про запобігання та протидію легалізації (відмиванню) доходів, одержаних злочинним шляхом, фінансуванню тероризму та фінансуванню розповсюдження зброї масового знищення : Закон України від 14.10.2014 № 1702-VII (у редакції від 24.11.2018). Відомості Верховної Ради України (ВВР). 2014. № 50-51. Ст. 2057.

7. Про засади запобігання i боротьби з корупцією: Закон України. Відомості Верховної Ради України (ВВР). 2011. № 40. Ст. 404 (утратив чинність 01.09.2016).

8. Агапов А.Б. Административная ответственность : учебник. Москва : Статут, 2000. С. 10.

9. Адміністративне право України : підручник / за ред. Ю.П. Битяка. Київ : Юрінком Інтер, 2007. С. 172-174.

10. Адміністративне право. Загальна частина : навчальний посібник / С.М. Алфьоров, С.В. Ващенко, М.М. Долгополова, А.П. Купін. Київ : Центр учбов. літ., 2011. С. 82.

11. Висєканцев О.О. Адміністративна відповідальність державного нотаріусу. Актуальні проблеми права: теорія $і$ практика. 2012. № 25. C. 190-197. URL: http://nbuv.gov.ua/UJRN/app_2012_25_23 (дата звернення: 06.11.2020).

12. Гончарова А.С. До питання кримінальної відповідальності нотаріуса. Молодий вчений. 2018. № 10 (62). С. 227-231.

13. Зілковська К.Л. Судова юрисдикція справ щодо оскарження нотаріальних дій та відмови у їх вчиненні. С. 44. Веб-сайт Національної бібліотеки України імені B.I. Вернадського. URL: http://www.nbuv.gov.ua/portal/Soc_Gum/ Vonu_prav/2010_22/06.pdf (дата звернення: 06.11.2020).

14. Комаров В. Проблеми латинського нотаріату: український досвід нормоутворення. Вісник Академії правових наук Украӥни : збірник наукових праць. 2007. № 1 (48). С. 137.

15. Кримінальне право України. Загальна частина : підручник / за ред. M.І. Мельника, В.А. Клименка. 5 вид., переробл. та допов. Київ : Атіка, 2009. C. 227-228. 
16. Миронов А.Н. Нотариат : учебное пособие. Москва : Форум ; Инфра-М, 2005. C. $75-76$.

17. Москаленко И.В. Сущность и значение нотариата. Нотариус. 2002. № 5. С. 6.

18. Уголовный кодекс Российской Федерации от 13 июня 1996 г. № 63-Ф3 (ред. от 3 июля 2018 г.). URL: http://ppt.ru/kodeks.phtml?kodeks=20 (дата звернення: 06.11.2020).

19. Vdovichen V., Vdovichena L. (2019). Professional Responsibility of Notaries: Ontological Aspect. Eur. JL \& Pub. Admin. 2019. № 6. P. 148.

\section{Information about authors:}

Vdovichen V. A.,

LL.D, Associate Professor,

Associate Professor at the Department of Public Law

Yuriy Fedkovych Chernivtsi National University

2, Kotsyubynsky str., Chernivtsi, 58012, Ukraine

Vdovichena L. I.,

$\mathrm{PhD}$,

Associate Professor at the Department of Public Law

Yuriy Fedkovych Chernivtsi National University

2, Kotsyubynsky str., Chernivtsi, 58012, Ukraine 